\title{
MEDICAL TOURISM IN POLAND - DEVELOPMENT PROPOSALS
}

\section{TURYSTYKA MEDYCZNA W POLSCE - PROPOZYCJE ROZWOJU}

\author{
Inessa Orekhovska ${ }^{1(\mathrm{~A}, \mathrm{~B}, \mathrm{C}, \mathrm{D}, \mathrm{E}, \mathrm{F})}$, Barbara Bergier ${ }^{1(\mathrm{~A}, \mathrm{D}, \mathrm{E}, \mathrm{G})}$
}

${ }^{1}$ Department of Tourism and Recreation, Pope John Paul II State School of Higher Education in Biała Podlaska, Poland

Authors' contribution Wkład autorów: A. Study design/planning zaplanowanie badań B. Data collection/entry zebranie danych C. Data analysis/statistics dane - analiza i statystyki D. Data interpretation interpretacja danych E. Preparation of manuscript przygotowanie artykułu F. Literature analysis/search wyszukiwanie i analiza literatury G. Funds collection zebranie funduszy
Tables: 1

Figures: 5

References: 34

Submitted: 2021 Apr 14

Accepted: 2021 Jun 1

\section{Summary}

Background. People have travelled for treatment-related purposes for a long time. Every year, the demand for such trips increases. The market of travelling because of one's health is a growing sector of the tourism economics. Poland is a country with a strong potential medicine-wise and may expand its capabilities with proper resource management (legal changes, personnel education, implementing new technologies and global promotion). One of the factors that encourages tourists to come to Poland are the prices of medical procedures much lower than in other countries in Europe and worldwide.

Material and methods. The study included individuals aged 18 to 56 from seven countries: Poland, Ukraine, Belarus, Russia, United Kingdom, Norway and Italy. A diagnostic survey and the questionnaire technique were used.

Results. Poland is visited by tourists of different age and their interest in the travels still grows. Contemporary medical tourism offers a wide range of services and each person (not only the actually ill) may explore them. The main purpose of the travels is health improvement, but there are also arguments regarding "changing oneself," relaxation and escaping civilization. The examined persons express their dissatisfaction with the state of the buildings at which they stayed during their treatments and personnel preparedness.

Conclusions. Medical tourism in Poland needs to undergo some changes to have a chance of developing on a global scale. Poland is an EU country with low prices of procedures and a high level of medicine.

Keywords: medical tourism, travel for treatment, Poland

\section{Streszczenie}

Wprowadzenie. Ludzie podróżowali w celach leczniczych od dawna. Co roku zapotrzebowanie na te wyjazdy wzrasta. Rynek związany z podróżami zdrowotnymi jest rozwijającym się sektorem ekonomiki turystyki. Polska jest państwem z silnym potencjałem medycznym i może rozwinąć swoje możliwości przy prawidłowym zarządzaniu zasobami (zmiany prawne, szkolenie personelu, wdrażanie nowych technologii i promocji na skalę światowa). Jednym z głównych czynników, który zachęca turystów by przyjeżdżali do Polski są ceny zabiegów - znacznie niższe niż w innych państwach Europy i świata.

Materiał i metody. Materiał badawczy stanowiły osoby w wieku od 18 do 56 lat z siedmiu państw: Polski, Ukrainy, Białorusi, Rosji, Wielkiej Brytanii, Norwegii i Włoch. Wykorzystano metodę sondażu diagnostycznego oraz technikę ankiety.

Wyniki. Polskę odwiedzają turyści w różnym wieku, a ich zainteresowanie wyjazdami ciągle wzrasta. Współczesna turystyka medyczna ma szeroki zakres usług i każda osoba (nie tylko chora) może z nich korzystać. Głównym motywem wyjazdów jest nadal poprawa zdrowia, ale pojawiają się również chęci „zmiany siebie”, odpoczynku i ucieczki od cywilizacji. Badani wskazali też niezadowolenie ze stanu obiektów w których przebywali podczas wyjazdów leczniczych i z przygotowania personelu.

Wnioski. Turystyka medyczna w Polsce potrzebuje zmian, by mieć szanse rozwoju na skalę światową. Polska to państwo unijne $\mathrm{z}$ niskimi cenami zabiegów oraz wysokim poziomem medycznym.

Słowa kluczowe: turystyka medyczna, wyjazdy lecznicze, Polska 


\section{Introduction}

The desire of the contemporary man to lead a healthy life and the fact that humans live longer observed in the developed countries, stemming from the progress of medicine, wider accessibility to medical procedures and food of better quality, led to a rise of new demands and directions in the sector of tourism services. The term "medical tourism" is a modern expression, but the very idea is not something new and unknown. It is often called "the phenomenon of the $21^{\text {st }}$ century", one of the consequences of progressing globalization of industries and mass culture.

According to J. Rab-Przybyłowicz, medical tourism regards “travelling outside one’s region or country with the purpose of staying at a doctor's office, clinic or hospital, in order to improve health or looks under the care of a medical specialist" [1].

Medical tourism has been developing since the Sumerian times (approx. 4000 years BC), took a new form in the Bronze Age (approx. 2000 years BC) related to the belief in the healing power of mineral springs rich in iron, to be further changed by the doctors in Ancient Greece and Rome. Medicine was no longer related to the power of gods, diseases were given a natural origin, first "medical centers" in the world were established, along with the "valetudinaria" that served as lazarettos (an archaic term for a war hospital, especially a field one). Throughout the existence of the human race, the search for the means of healing and treating various diseases has been in progress. Places in which healing springs were discovered became the destinations of pilgrimages of medical tourists [2-5]. In early 2000, Asian countries - mainly Thailand and Singapore - changed their laws and started performing surgical procedures banned in other countries (e.g., gender reassignment) [4].

In line with the growing demand and supply in medical tourism, the Joint Commission International (JCI), approved by the World Health Organization, was established in 1997 to monitor the activity of medical institutions in terms of compliance with international standards. The Joint Commission (JC) is a non-profit organization headquartered in the United States, which started its activity in 1951 and currently has 3 separate commissions for medical purposes $[3,6,7]$. By gaining JC's approval, medical institutions elevate their position on the medical market.

Currently, the term "medical tourism" is becoming increasingly popular and is classified as one of the forms of health tourism, along with resort tourism and SPA and Wellness. While analyzing terminology related to medical tourism, it was noticed that both Polish and foreign sources contain many inaccuracies, and the described terms are often mutually exclusive [8]. It is probably related to the fact that this set of terms is still being perfected. Medical tourism is an element of national and international tourism as well as intranational tourism [9]. Source literature featured expressions such as: "medical tourist", "medical traveler", "medical value traveler", "global healthcare traveler". When tourists travel within their country for medical purposes, it is classified as treatment tourism. Medical tourism is tied with other forms of tourism by the necessity to travel outside the place of permanent residence, but the main motif is solely the improvement of health or body aesthetics taking place under the care of a medical practitioner, in a doctor's office, a clinic or a hospital [10-12].

According to the Bloomberg agency report (2019), it is expected that the global market of medical tourism will grow by the astounding 14.9\% in the years 2017-2025. In 2016, the sector reported an estimated income of 46.46 bln USD, which will probably grow to the estimated 160.8 bln USD by the end of 2025. Developing countries offer state-of-the-art methods of treatment and surgeries at competitive, lower prices [13].

In 2016, the most popular services provided within the category of global medical tourism were: plastic surgery, dentistry, cardiology, orthopaedics, oncology and procedures related to in vitro fertilization (often because of the lack of legal regulations) [14,15].

Medical tourism in Poland will develop more and more dynamically [8]. The medical services in our country are cheaper by $30 \%$ to $65 \%$ if compared to the services in Germany, United Kingdom and Belgium. Airways also play an important role here; plane tickets are not expensive and, frequently, the costs of the procedure with the travel expenses are lower than the costs of the procedure in the tourist's country of residence (Table 1, Figure 1).

Table 1. Prices of services in medical tourism (in USD) [8]

\begin{tabular}{|c|c|c|c|c|c|c|c|}
\hline \multirow{2}{*}{ Procedures } & \multicolumn{7}{|c|}{ Countries } \\
\cline { 2 - 8 } & USA & India & Thailand & Singapore & Malaysia & Mexico & Poland \\
\hline Bypassing & 113000 & 10000 & 13000 & 20000 & 9000 & 3250 & 7140 \\
\hline $\begin{array}{c}\text { Heart ventricle } \\
\text { replacement }\end{array}$ & 150000 & 9500 & 11000 & 13000 & 9000 & 18000 & 9520 \\
\hline Angioplasty & 47000 & 11000 & 10000 & 13000 & 11000 & 15000 & 7300 \\
\hline Hip replacement & 47000 & 9000 & 12000 & 11000 & 10000 & 173000 & 6120 \\
\hline Knee replacement & 48000 & 8500 & 10000 & 13000 & 8000 & 14650 & 6375 \\
\hline
\end{tabular}


Figure 1 presents the increasing percentage of persons declaring their travel to Poland for pro-health purposes in the years 2012-2013.

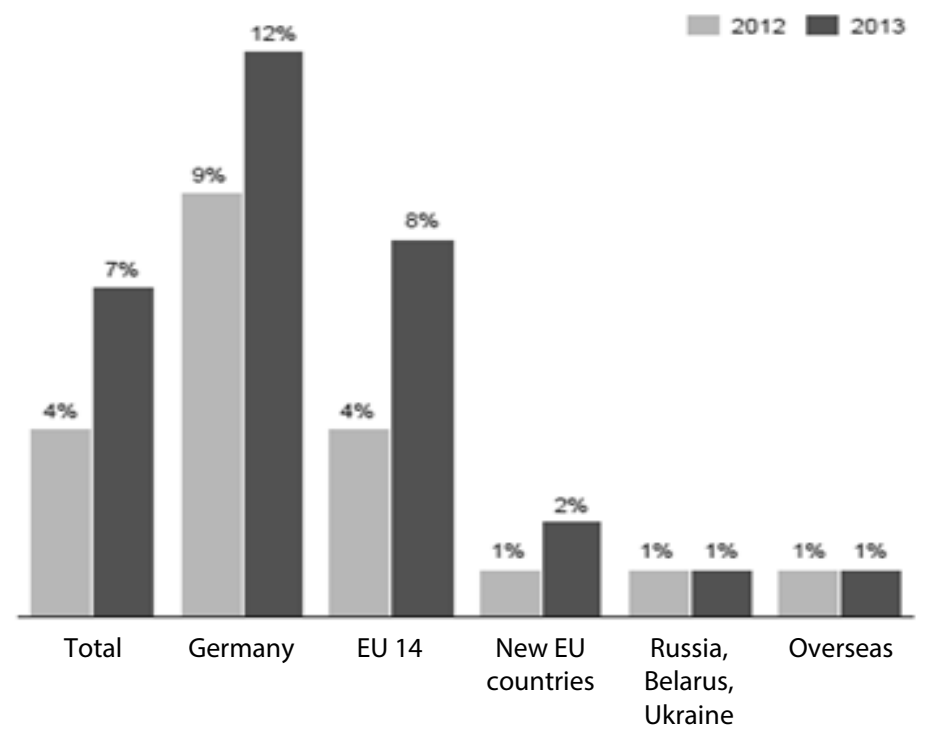

Figure 1. Persons declaring their travel to Poland for pro-health purposes [16]

According to the research of the Treatment Abroad agency conducted in the United Kingdom in 2012 on a group of 1000 persons, the most popular destinations for medical procedures in Europe are:

- Belgium (16\%),

- Hungary (15\%),

- Poland (10\%),

- Czech Republic (9\%),

- Turkey (9\%),

- Spain (7\%) [17].

The aim of the paper was to determine the proposals for developing medical tourism in Poland and investigate into the preferences of tourists in terms of treatment travels in 2019. The respondents were asked about the destinations of their travels, types of selected facilities, procedures they underwent and reasons for dissatisfaction with their travel.

\section{Material and methods}

In April 2020, an anonymous questionnaire was carried out on-line. The original questionnaires were prepared by means of the internet platform "Google Forms" in three languages - Polish, Russian and English. Links to the questionnaires were placed on the internet fora regarding treatment abroad (in various countries). They were completed by 143 persons. The questionnaires were prepared in three language versions to expand their reach and include diverse respondents. The study included people from seven countries - Poland, Ukraine, Belarus, Russia, United Kingdom, Norway and Italy. The largest groups were persons from Ukraine (33\%), Poland (30\%) and Russia (25\%). The majority of respondents turned out to be women (67\%), while the remaining $33 \%$ were male. Respondents aged from 18 to 59. Most of them (67\%) lived in large cities.

\section{Results}

The preferred destinations disclosed by the respondents were the following regions: Northern Europe (31\%), the Mediterranean (23\%), Asia and the Black Sea (19\% each). Women mainly travelled to Northern Europe (25\%), the Mediterranean and the Black Sea regions (17\% and 13\%, respectively). Asia was the destination of medical travels of a similar percentage of women and men ( $9 \%$ and 10\%, respectively). Northern Europe was chosen most often by persons between 36 and 45 years of age and between 26 and 35 years of age (18\% and 9\%, respectively).

In 2019, treatment travels to Russia (14\%), Poland (13\%), Hungary and Ukraine (12\% each) were the most popular among respondents in 2019 (Figure 2). 


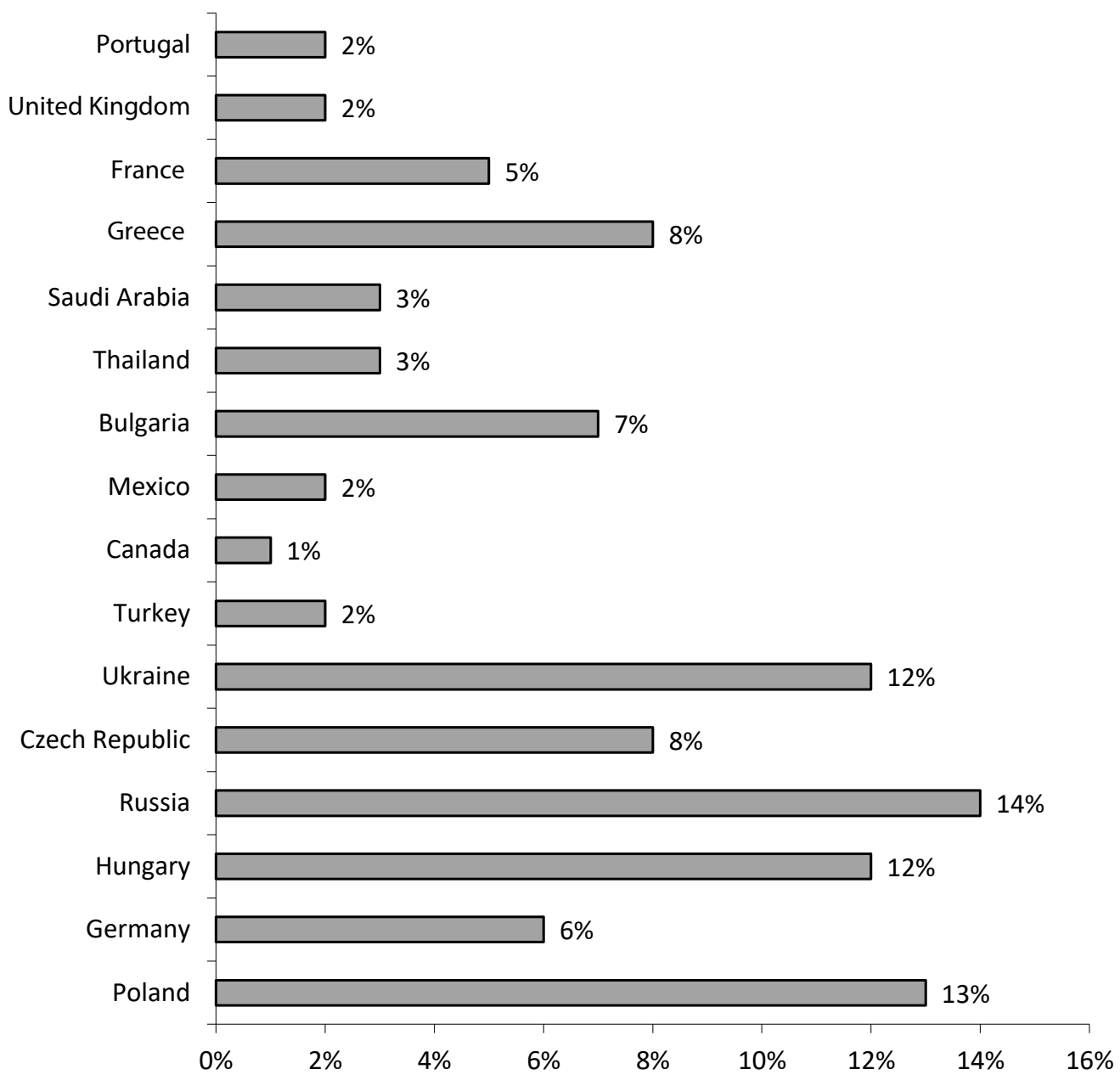

Figure 2. Treatment travels of the respondents in 2019

According to own research, respondents arriving in Poland in 2019 chose for their treatment needs mostly the Baltic Sea region (24\%), resorts (20\%) and the mountains (19\%). Poland was selected by persons from the 46-55 and 18-25 age groups. It may mean that our country appeals to both older and younger people and offers them a wide range of medical services.

The main motivation for the travel was treatment and regeneration of physical and mental strength. Apart from health-related reasons, the arguments related to "changing oneself" (plastic surgeries, caring for the body) and escaping civilization appear more and more often. It stems from the fact that the sector is facing new challenges as contemporary tourists look for more than just improving their health. In the questions on the number of days devoted to the treatment stay, the respondents mainly pointed to travels of up to 7 days (33\%) and 21-day stays (25\%).

The respondents were also asked about their satisfaction with their treatment travels in 2019. Main reasons for discontent were the state of the facilities (63\%) and the preparedness of the personnel $(17 \%)$. It points to the need to modernize and renovate the existing medical facilities in Poland and prepare the personnel better. Facilities that target tourists from other countries need to invest in both good equipment and personnel training.

Most of the medical tourists used non-public hospitals and resorts. Most persons travelled individually (78\%) for treatment purposes, only $22 \%$ of respondents used the services of intermediaries. Women (15\%) were more willing to use intermediary companies than men (7\%). It may suggest that either the information on foreign facilities and treatments are becoming more accessible to tourists or that there is an insufficient number of intermediaries, and their prices are too high. It is similar to other forms of tourism. There are persons who are willing to use the services of travel organizers and persons who want to plan their travels on their own.

Most of the respondents chose plastic surgery procedures (26\%) and weight reduction treatments (22\%). The least respondents decided to undergo cardiological intervention (2\%). The above data may confirm that 
patients are starting to use medical services not only to take care of their health, but also to improve their looks, change themselves and get rid of insecurities (Figure 3).

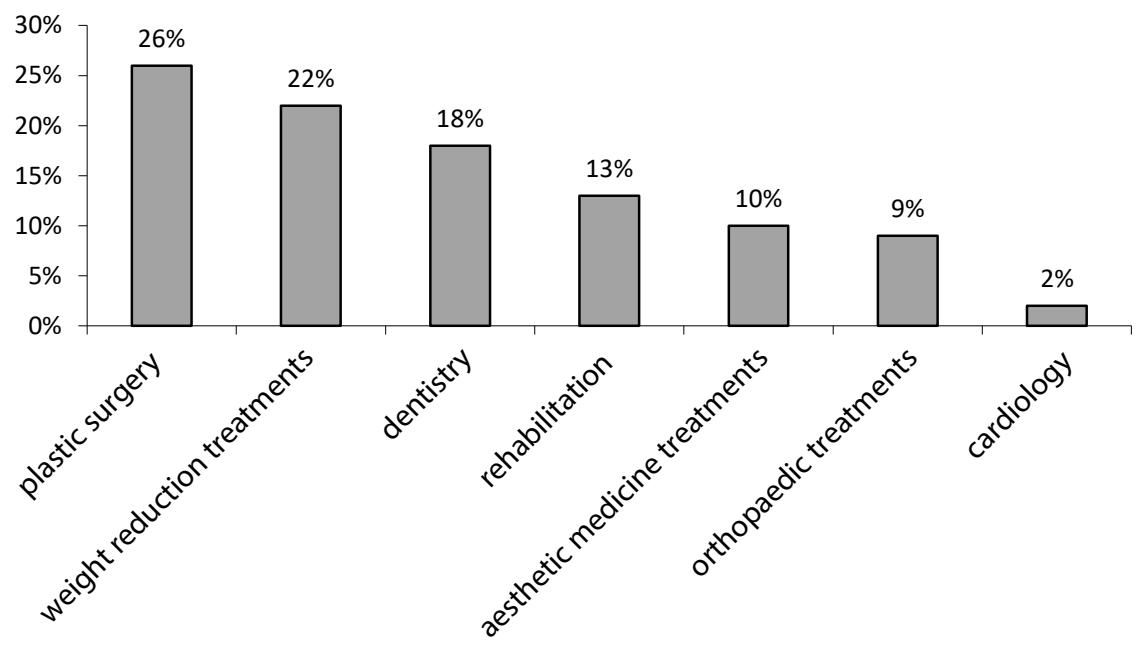

Figure 3. Procedures the respondents underwent in 2019

\section{Discussion}

During the COVID-19 pandemic, medical tourism entered a new stage of providing medical services. Tourists travel to other countries to get vaccinated with a product unavailable in their country of residence. Some go to countries with a lower pandemic-related risk, so they have a chance of being admitted to hospitals and undergo necessary procedures.

Most countries discuss the introduction of the so-called "green passports" in the "Travel Pass" application. It would include information on the tests and vaccinations against COVID-19. There are also countries (such as France) that oppose the introduction of such mobile data as they see it as means of discriminating against persons that do not want to be vaccinated [18,19].

According to the MedicalTourism agency report for the years 2020-2021, in a global rank of countries (prepared on the basis of the MTI index), Poland is in $29^{\text {th }}$ place and in the European region, it occupies $7^{\text {th }}$ place (Figure 4). In 2016, Poland was $24^{\text {th }}$ in the global ranking and $19^{\text {th }}$ in 2015. The Medical Tourism Index (MIT) is a new type of efficiency measurement used to evaluate the attractiveness of a country as a center for medical tourism. MTI is a global point of reference in terms of the countries being attractive destinations for medical tourisms after assessing and analyzing the country's state. It considers 41 criteria of evaluating a country to reflect the needs of medical tourists (safety, accessibility, attractiveness, quality, offered services, prices, etc.) [20]. Data included in the report suggest that the Polish market of medical tourism needs modernization and promotion on the international arena, which is also confirmed by the results of the author's own research. 


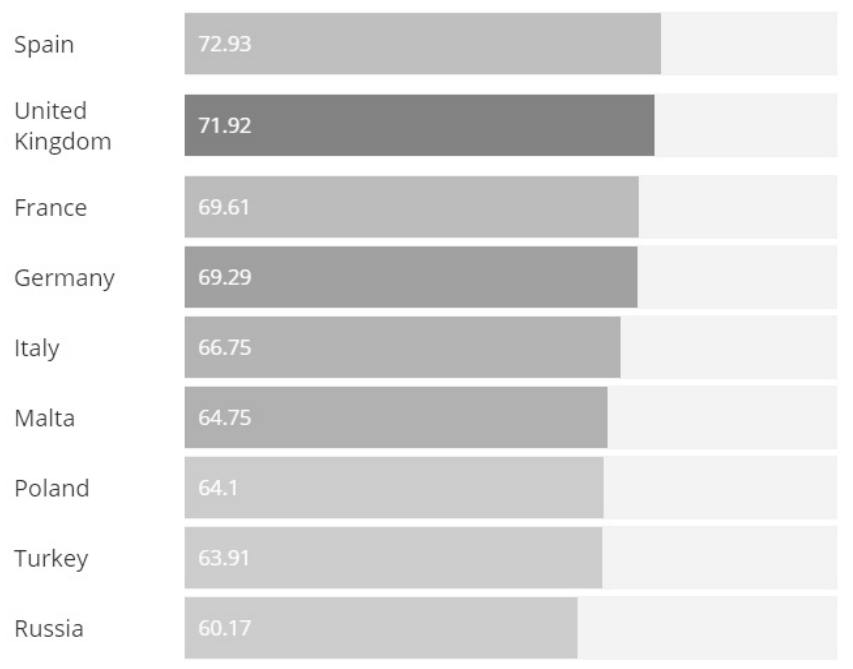

Figure 4. The general result of the Medical Tourism Indicator in Europe [20]

In 2017, the on-line portal BookingHealth highlighted Poland in two popular directions of medical tourism - dentistry and ophthalmology [21]. These results show Poland's strengths on the international market. Taking them into consideration, it is possible to conclude that the government should continue the works in the appreciated medical services by promoting them worldwide and also develop other services to expand their offer to foreign customers [22].

Poland is visited by tourists not only from neighboring countries and Europe but also from all over the world (Figure 5).

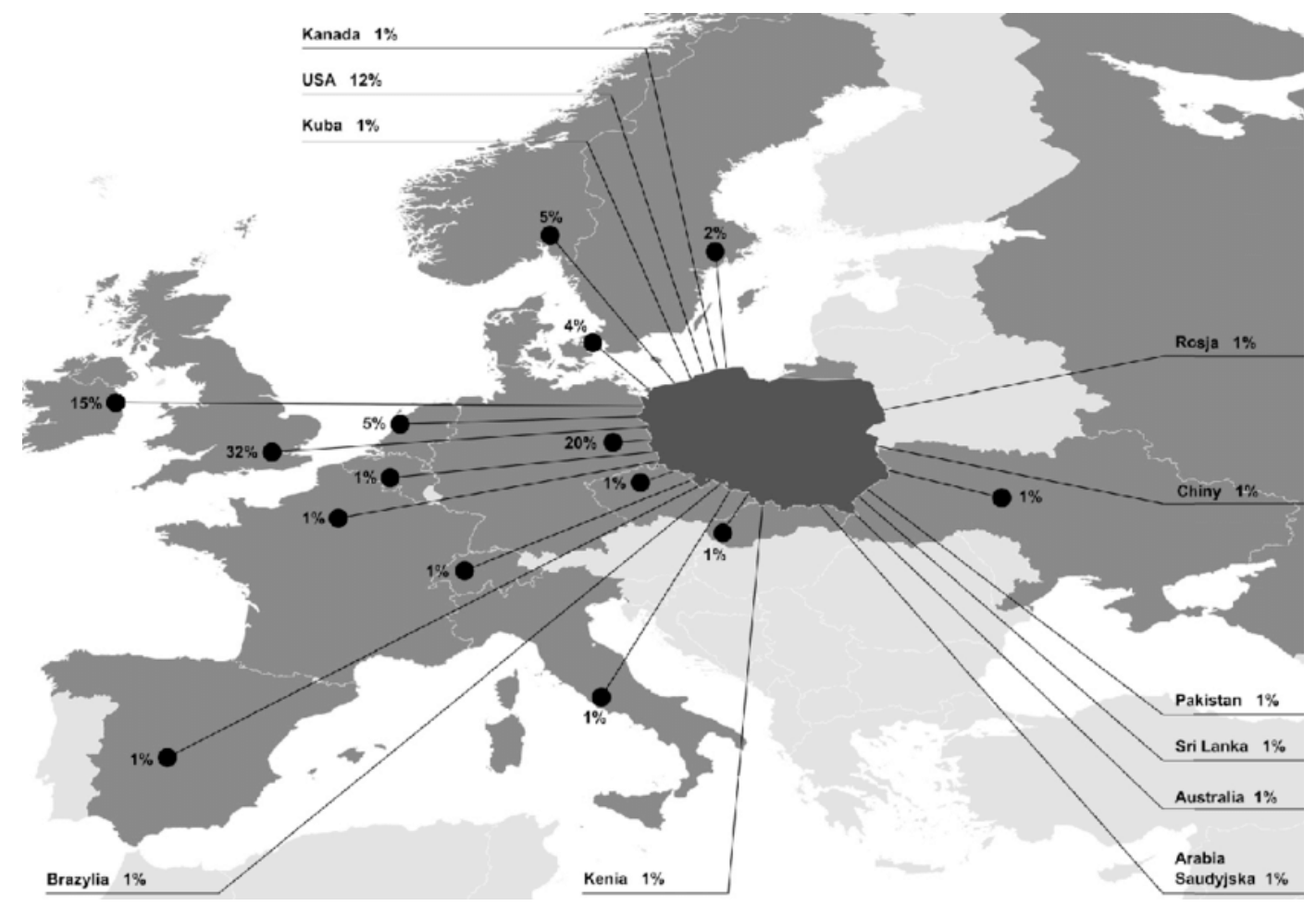

Figure 5. Arrivals of medical tourists to Poland [23]

Notes: Kanada - Canada, USA - USA, Kuba - Cuba, Brazylia - Brazil, Kenia - Kenya, Arabia Saudyjska - Saudi Arabia, Australia - Australia, Sri Lanka - Sri Lanka, Pakistan - Pakistan, Chiny - China, Rosja - Russia. 
Some of the popular medical destinations in Poland are:

- Medical complex "Ustroń",

- Rehabilitation center "Rehamed-Center" in Rzeszów,

- Duda Clinic in Katowice,

- Mazan Surgery Clinic in Katowice,

- Medifem in Warsaw,

- Indexmedica in Cracow,

- European Health Center in Otwock,

- Mandala Beauty Clinic in Poznań [24].

According to McKinsey's research, main (globally) motivations for travelling were: the necessity to undergo a procedure using modern technologies (42\%), medical services of higher quality (33\%), need for urgent help (15\%) and wanting to save money on treatment [25]. The Transparency agency report (2020) suggests that the availability of state-of-the-art medical technologies and wider opportunities for treatment as well as the increased compliance with international quality standards are the key factors affecting the market of medical tourism. Patients care more and more about the continuity of care in medical facilities - from admission to rehabilitation [26].

In the lastseveralyears, the market of medical tourism in Poland did not develop as rapidly as in other countries. Medicine in Poland demands system changes that would encompass the personnel, facilities, organization, laws and promotion on the international market. Over 50 countries in the world handles the development of medical tourism on the level of state policy [22,27]. Countries such as Turkey and Malaysia subsidize the treatment of foreign tourists, and South Korea covers the insurance risk when it comes to the medical treatment of foreigners [28].

COVID-19 has changed the market of medical tourism. According to research by the Center for Medical Tourism Research (located in the H-E-B School of Business \& Administration at the University of the Incarnate Word in San Antonio, Texas - leading global academic research center dealing with medical tourism), the demand for essential operations is growing after over 177000 planned surgeries were delayed in the United States between March and June 2020. The number of health-related travels has grown by $64 \%$ in the USA only (in 2019, it reached 32\%). These travels are still taking place, but in a different manner than before the pandemic. After it ends and the borders are opened, the world will be different. Both tourism and medical tourism will need new rules and solutions that enable safe travelling [29-32].

The tourism sector should be ready as tourists will soon be asking for more than just improving their health. Nowadays, medicine allows people to treat their diseases and improve their physical condition, but also model their appearance and, consequently, upgrade their mental well-being - helping to get rid of insecurities in their mentality. Weight loss, orthopaedics, cosmetology are still popular services within medical tourism [33,34].

\section{Conclusions}

Modern medical tourism offers a wide array of services and everyone - not only the ones troubled with diseases - may benefit from them. Apart from health-related motivations, there are also other reasons "changing oneself" (e.g., plastic surgery, breast enlargement, gender reassignment) and related to escaping from civilization and prestige.

To help the medical tourism market in Poland develop, attention should be devoted to the quality of medical services, using modern technologies and employing personnel qualified to assist foreign customers. Facilities that should match the tourists' expectations should be renovated, both in terms of the offered procedures and their general state. They should include areas of relaxation, rooms for children and facilities for visitors with animals.

Promoting Poland on the global market of medical tourism is also important. Apart from general promotion, services that are now "trademarks" of Poland and are still expanding should be highlighted as well. Promoting the services of medical tourism should also be adjusted to the country in which its data will be presented. In the west, it is worth promoting services that are cheaper in Poland but at a high level (e.g., dentistry); in the east, services that are unavailable there or of poor quality (e.g., rehabilitation, cardiology).

Based on the experience, research results and examples from other countries, it is possible to establish in Poland a well-developed market of medical tourism with a wide range of services over the next few years. The COVID-19 pandemic showed how important health and medical care are nowadays. 


\section{References:}

1. Rab-Przybyłowicz J. [Product creation for Szczecin’s medical tourism]. Ekonomiczne Problemy Usług. 2010; 53: 695-706 (in Polish).

2. Andreeva N. [Medical tourism as a modern trend of development]. In: Snarski J, Jalinik M., editors. [Entrepreneurship in tourism]. Białystok: EkoPress; 2014 (in Polish).

3. Dąbrowska-Zielińska K, Wołk-Musiał E. [Health-resort tourism in Poland and worldwide - perspectives for the development of Spa and Wellness in Poland]. Warszawa: PWE; 2012 (in Polish).

4. Tastanbekova SO. [Medical tourism: beginnings, importance and definitions]. Astana: Ranimed; 2016 (in Russian).

5. Dracheva E. [Medical tourism]. Moscow: KNORUS; 2008 (in Russian).

6. Joint Commission International. JCI Hospital Standards [Internet]. Oak Brook: Joint Commission International [cited 2021 Jan 13]. Available from: https://www.jointcommissioninternational.org/accreditation/ accreditation-programs/hospital/

7. pl.qaz.wiki [Internet]. San Francisco: Wikimedia Foundation, Inc. Joint Commission [cited 2021 Jan 13]. Available from: pl.qaz.wiki/wiki/Joint_Commission (in Polish).

8. Kelley E. Medical tourism. Geneva: WHO; 2013.

9. Lubowicki-Vikuk AP. [Medical tourism as an indication of the modern trends and tendencies in tourism]. Toruń: Uniwersytet Mikołaja Kopernika w Toruniu; 2012 (in Polish).

10. Rab-Przybyłowicz J. Medical tourism: theoretical considerations. Studia Periegetica. 2016; 16(2): 16-31.

11. SEKRETYKOBIET.COM.PL [Internet]. Kraków: Fusion Marketing Sp. z o.o.; 2016 Jul 20. [Medical tourism in Poland and worldwide] [cited 2021 Jan 15]. Available from: https://www.sekretykobiet.com.pl/podroze/ rsfy/turystyka-medyczna-w-polsce-i-na-swiecie.html (in Polish).

12. Białk-Wolf A. [Health-resort tourism as a form of medical tourim]. In: Boruszczak M., editor. [Medical tourism]. Gdańsk: Wydawnictwo WSTiH; 2010 (in Polish).

13. Bhisey R. Medical tourism market to exceed US $\$ 160.8$ billion due to increasing demand for advanced treatment therapies across the globe [Internet]. New York: Bloomberg L.P.; 2019 Jun 12 [cited 2021 Jan 15]. Available from: https://www.bloomberg.com/press-releases/2019-06-12/medical-tourism-market-toexceed-us-160-8-billion-due-to-increasing-demand-for-advanced-treatment-therapies-across-the-globe

14. Travco Health Tourism [Internet]. Istanbul: Travco Health Tourism. [Health tourism: statistics and facts] [cited 2021 Jan 21]. Available from: http://ru.healthtourism.pro/spravochnik-med-turizma/meditsinskiyturizm-statistika-i-fakty/ (in Russian).

15. bookinghealth.com [Internet]. Remagen: Booking Health GmbH; 2017 Jan 18. TOP 10 global trends in healthcare services [cited 2021 Jan 21]. Available from: https://bookinghealth.com/blog/medical-tourism/ treatment-abroad-guides/289988-top-10-trendy-healthcare-services-in-the-world.html

16. Tourism Department of the Ministry of Sport and Tourism. [Characteristics of non-residents' arrivals at Poland in 2016 based on the statistical research of Statistics Poland - Ministry of Sport and Tourism - National Bank of Poland]. Warsaw: Tourism Department of the Ministry of Sport and Tourism; 2017 (in Polish).

17. Rutkowska M. [The potential and the development of the medical tourism market in Poland and worldwide] [Internet]. Gdańsk: Gdańska Organizacja Turystyczna; 2014 [cited 2021 Jan 22]. Available from: http://trendywturystyce.pl/wp-content/uploads/2014/03/Rozw\%C3\%B3j-i-potencja\%C5\%82-rynkuturystyki-medycznej-w-Polsce-i-na-\%C5\%9Bwiecie.pdf (in Polish).

18. Cohen C. [Covid-19: could a "vaccination passport" to access certain places and services exist in France?] [Internet]. Paris: Le Figaro; 2021 Jan 11 [cited 2021 Jan 22]. Available from: https://www.lefigaro.fr/conso/ covid-19-un-passeport-vaccinal-pour-acceder-a-certains-lieux-et-services-pourrait-il-voir-le-jour-enfrance-20210111 (in French).

19. laingbuissonnews.com [Internet]. London: LaingBuisson. IATA unveils details of travel PASS [cited 2021 Jan 15]. Available from: https://www.imtj.com/news/iata-unveils-details-travel-pass

20. MedicalTourism.com [Internet]. West Palm Beach: Medical Tourism Association. Medical Tourism Index 2020-2021 [cited 2021 Jan 15]. Available from: https://www.medicaltourism.com/mti/2020-2021/region/ europe

21. bookinghealth.com [Internet]. Remagen: Booking Health GmbH; 2017 Jul 28. Medical tourism is a new concept in global healthcare [cited 2021 Jan 15]. Available from: https://bookinghealth.com/blog/medicaltourism/303352-medical-tourism-is-a-new-concept-in-global-healthcare.html 
22. Szlechta JM. [Medical tourism - a Polish way]. Clark: Nowy Dziennik Polish Weekly News; 2019 Jul 29 [cited 2021 Jan 22]. Available from: http://dziennik.com/wiadomosci/polska/turystyka-medyczna-po-polsku/ (in Polish).

23. Lubowiecki-Vikuk A, Rab-Przybyłowicz J. [Selected aspects of the functioning of the medical tourism market in Poland]. Folia Turistica. 2015; 34: 85-107 (in Polish).

24. fostertravel.pl [Internet]. Warszawa: Fostertravel.pl Sp. z o.o. [Medical tourism] [cited 2021 Jan 23]. Available from: https://www.fostertravel.pl/turystyka-medyczna/ (in Polish).

25. Ehrbeck T, Guevara C, Mango PD. Mapping the market for medical travel. The McKinsey Quarterly. 2008; May: 1-11.

26. transparencymarketresearch.com [Internet]. Pune: Transparency Market Research. Medical tourism market (medical treatment - cosmetology, dentistry, cardiology, orthopedic surgery, neurology, and oncology) global industry analysis, size, share, growth, trends, and forecast 2019-2027 [cited 2021 Jan 15]. Available from: https://www.transparencymarketresearch.com/medical-tourism.html

27. PwC Polska. [Trends in the Polish healthcare] [Internet]. Warszawa: PwC Polska Sp. z o.o.; 2017 [cited 2021 Jan 15]. Available from: https://www.pwc.pl/pl/pdf/9-trendow-w-ochronie-zdrowia-2017-pwc.pdf (in Polish).

28. Meštrović T. What is medical tourism [Internet]. Manchester: News-Medical.Net; 2018 Aug 23 [cited 2021 Jan 15]. Available from: https://www.news-medical.net/health/What-is-Medical-Tourism.aspx

29. Arent M. [Medical tourism operates despite the pandemic] [Internet]. Gdańsk: Turystyka Medyczna; 2021 Feb 3 [cited 2021 Jan 16]. Available from: https://turystyka-medyczna.com/turystyka-medyczna-trwapomimo-pandemii/ (in Polish).

30. Gelman VY. [Public health disparities and medical tourism]. Medicine. 2017; 4: 21-32 (in Russian). https://doi.org/10.29234/2308-9113-2017-5-4-21-32

31. my.uiw.edu [Internet]. San Antonio: University of the Incarnate Word. The Center for Medical Tourism Research (CMTR) [cited 2021 Jan 16]. Available from: https://my.uiw.edu/medical-tourism/index.html

32. Yeginsu C. Why medical tourism is drawing patients, even in a pandemic [Internet]. New York: New York Times; 2021 Jan 19 [cited 2021 Feb 2]. Available from: https://www.nytimes.com/2021/01/19/travel/ medical-tourism-coronavirus-pandemic.html

33. Marchenko O. World medical tourism is shifting to the countries of the Asia-Pacific region. Analytical Review. 2013; 6: 1-12.

34. kliniki.pl [Internet]. Łódź: Kliniki.pl Sp. z o.o; 2016 Jul 18. [Medical tourism in Poland - which medical treatments were the most popular among foreigners in 2015] [cited 2021 Feb 2]. Available from: https://www.kliniki.pl/wiedza/turystyka-medyczna-w-polsce-jakie-zabiegi-sa-najpopularniejsze-wsrodobcokrajowcow/ (in Polish). 